\title{
Prediction of Elastic Properties using Crossplot Analysis and Seismic Inversion for Enhanced Quantitative Interpretation of Zeta Field, Niger Delta, Nigeria
}

\author{
P. S. Nwiyor'1, E. D. Uko², I. Tamunobereton-ari', A. R. C. Amakiri' ${ }^{4}$, O. A Davies ${ }^{5}$ \\ Science Laboratory Technology Department, Ken Saro Wiwa Polytechnic, Bori, Nigeria ${ }^{1}$ \\ Physics Department, Rivers State University, Nkpolu-Oroworukwo, Rivers State, Nigeria ${ }^{2}$
}

\begin{abstract}
Prediction of elastic properties using crossplot analyses and seismic inversion quantitative interpretation in Zeta field was carried out to improve quantitative interpretation in the field. The dataset used comprises of well logs and full stack seismic data. Rock attribute properties modelled from well logs and analysed in the cross-plot space show strong sensitivity to reservoir lithology and fluids. The cross-plot of lambda-rho $(\lambda \rho)$ versus mu-rho $(\mu \rho)$ distinguishes the reservoirs into shale, brine sands, oil sands and gas sands. The cross-plots show that hydrocarbon sands have low $\lambda \rho$ and high $\mu \rho$ values. $\lambda \rho$ is sensitive to fluid and $\mu \rho$ sensitive to rock matrix only. This makes $\mu \rho$ versus $\lambda \rho$ a good fluid discriminator. This suggests that the inversion result could be useful to distinguish sands from shale and brine from oil. Simultaneous seismic inversion method was applied to transform seismic reflection data into quantifiable rock properties. Results reveal low lambda-rho values which are indicative of hydrocarbon saturated-sands. These values confirm the availability of hydrocarbons around Wells $3,4 \& 5$ locations and to the North-west of the horizon's slices. However, shale zones and brine are observed to the western part of the field and surrounding the hydrocarbon zones, indicating probable depleted zones and/or source rock. Moderately compacted clean hydrocarbon filled reservoir sands exhibits relatively high values of mu-rho due to their high opposition to shearing, while unconsolidated clean hydrocarbon saturated reservoir formations exhibit low mu-rho values. The inversion indicates that lambda-Rho attribute is more diagnostic of fluid characterization. This study can be applied in identification of new prospects as an effective economic and decision-making tool.
\end{abstract}

Keywords: Lambda-Rho, Mu-Rho, Simultaneous Inversion, Elastic Properties.

\section{INTRODUCTION}

Reservoir characterisation is the development of a detailed understanding of the reservoir, how it is put together and how it reacts to the production strategy [1]. The ultimate goal of any oil industry is to explore and produce hydrocarbon in an economic, safe and environment-friendly manner. This could be achieved through an accurate study of the reservoirs to understand and identify the flow units of the reservoir and predict the inter-well distributions of relevant petrophysical properties. By applying reservoir characterization techniques in a field, asset holders will be able to maximally recover hydrocarbon while minimizing costs [2]. Optimal placements of new wells and infill wells are also possible.

Elastic properties are those physical properties of a rock such as compressional wave velocity (Vp), shear wave velocity $(\mathrm{Vs})$, bulk density $(\rho)$, porosity, compressibility and their derived attributes that will affect how seismic waves physically travel through the rock [3]. Rock physics is very vital and serves as the connection that links elastic properties (Vp, Vs and $\rho$ ) to the reservoir properties such as lithology and fluid [4]. It is a connection that links the elastic properties to the reservoir properties such as water saturation, porosity and shale volume [5]. The reservoir parameters such as lithofacies, porosity, pore fluid type, saturation and pore pressure can be very well understood with the aid of rock physics. Cross plotting of rock properties from well logs is a very suitable and effective way of studying several rock properties or their attributes at the same time [6]. It shows quite decisively which rock properties or their attributes will be supportive in discriminating both lithology and fluid content in a particular reservoir. Rock physics can therefore be applied to predict reservoir parameters, such as lithologies and pore fluids derived from seismic attributes, especially in undrilled areas using seismic data and thereby reducing risks of exploration [7].

Seismic inversion is an important method to obtain subsurface structures and petrophysical information from seismic data and well $\log$ data. Inversion of seismic data is usually performed to obtain information about the P-wave impedance, which provides reliable information about the reservoir lithological properties [8]. Impedance inversion is a tool to derive seismic attributes (P-impedance, Poisson's ratio) that can be linked to rock properties (lithology, porosity, pore fluids) 


\section{International Advanced Research Journal in Science, Engineering and Technology \\ Impact Factor $7.105 \div$ Vol. 9, Issue 1, January 2022 \\ DOI: 10.17148/IARJSET.2022.9126}

using rock physics model and statistical techniques [4]. The physical parameters that are of interest to a modeler performing inversion are: Impedance $(\mathrm{Z}), \mathrm{P}$-wave $(\mathrm{Vp})$ and $\mathrm{S}$-wave (Vs) velocity and density. Lame parameters which are sensitive towards fluid and saturation in rocks can be derived from inverted models of impedances [9]. The petrophysical parameters like porosity, volume of shale and fluid saturation can be estimated with the help of inverted volumes [9]. In seismic inversion, the principal thing is the conversion of seismic properties into rock and fluid properties [10].

In this present study, rock physics models for litho-fluid interpretation of well log data and inversion results were applied. The work began by cross plotting rock properties and attributes for the prime motive of investigating their sensitivity to fluid and lithology in the cross-plot space. Then seismic inversion was done to derive different rock attributes. The combination of these techniques paved way to decrease the uncertainty of seismic interpretation and to investigate remaining prospectivity in the study field.

\section{LOCATION AND GEOLOGIC FRAMEWORK}

Zeta field is pseudo name given to the study field for proprietary reasons. The datasets used for the study were acquired in Coastal Swamp Depositional Belt, Onshore Niger Delta field, Nigeria. Fig. 1 shows the Niger Delta Map \& Base Map of the study area. The study area is located in Rivers State, approximately $85 \mathrm{~km}$ North-West of Port Harcourt situated in the Niger Delta Basin. The Niger Delta is included amongst the largest provinces that produce hydrocarbons. The latitudinal and longitudinal dimension of Niger Delta lie along the coordinates $\left(4^{\circ} \mathrm{N}-9^{\circ} \mathrm{N}\right.$ and $\left.4^{\circ} \mathrm{E}-9^{\circ} \mathrm{E}\right)$ and is globally one of the main hydrocarbon regions [11]. The lithostratigraphic sequence of the Niger Delta are; the marine shales of the Akata Formation (source rock), interstratified sandstones, siltstones and shales of the paralic Agbada Formation (source and reservoir rocks), and the continental alluvial sands and clays of the Benin Formation (overburden rocks), all of which are diachronous [12,13,14]. The structural styles in the Niger Delta are shale diapirs, roll-over anticlines, collapsed growth fault crests, back-to-back features, and steeply dipping, closely spaced flank faults [15]. These structures form the excellent migration pathways and entrapment mechanisms for hydrocarbon accumulation [16]. Niger delta reservoirs thickness is usually between $45 \mathrm{ft}$ to $150 \mathrm{ft}$ or more and it thickens toward down-thrown sides of growth faults $[13,17,18]$. Throughout the geologic history of the delta, its structure and stratigraphy have been controlled by the interplay between rates of sediment supply and subsidence [19]. Important influences on sedimentation rates have been eustatic sea-level changes and climatic variations in the hinterland. Subsidence has been controlled largely by initial basement morphology and differential sediment loading of unstable shale [14].

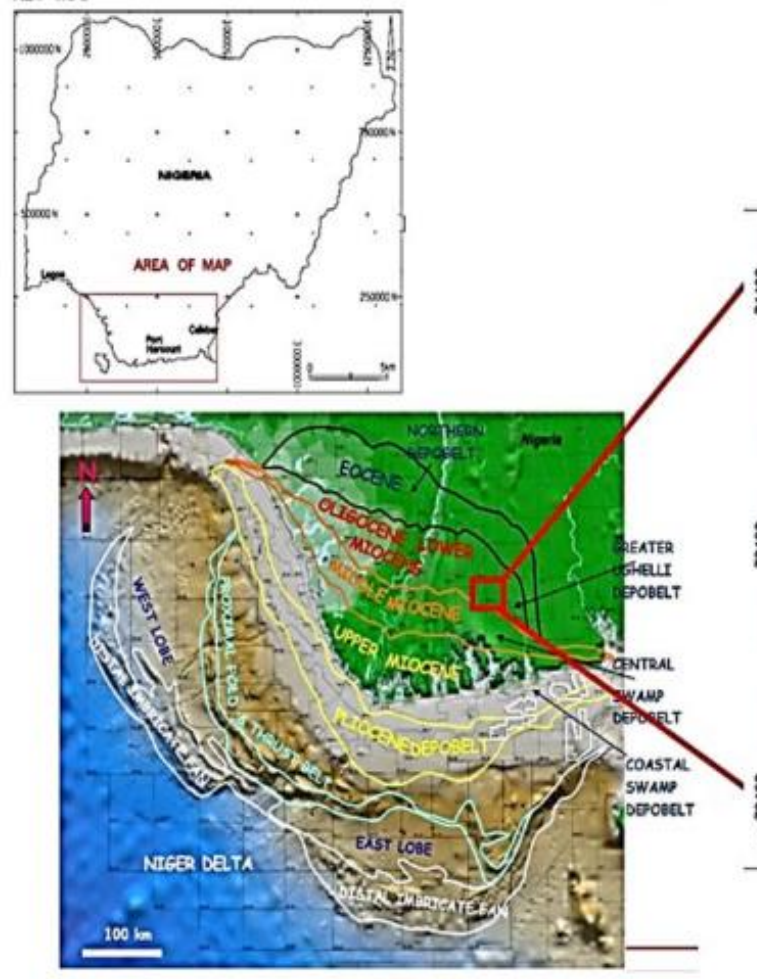

Fig. 1: Niger Delta Depositional Belt Map \& Base Map of the study area. 
International Advanced Research Journal in Science, Engineering and Technology

Impact Factor 7.105 Vol. 9, Issue 1, January 2022

DOI: 10.17148/IARJSET.2022.9126

III. DATA SETS AND METHODOLOGY

The data sets are a 3D full stack and suites of wire line log. For proprietary reasons, the wells are renamed as Well 1 , Well 2, Well 3, Well 4 Well 5, Well 6, and Well 7. Well log inventory of available wells in Zeta field is shown in Table 1. The composite well logs include calliper, gamma ray, compressional sonic log, resistivity etc. The given seismic data has a dominant frequency of $60 \mathrm{~Hz}$. Fig. 2 shows the seismic data in 3-D view. The seismic volume extends to 5000 milliseconds two-way travel time (TWT), below $3200 \mathrm{~ms}$ reflection continuity is poor. The 3D seismic data is characterized by a series of parallel reflections offset and deformed by major normal faults. Reflections around 1900 to $3000 \mathrm{~ms}$ have moderate to strong continuity and high amplitude variations. Reflections in the shallowest $2500 \mathrm{~ms}$ TWT of the seismic volume are parallel, nearly horizontal, and continuous. The shallow part of the seismic record (between 0 and $1000 \mathrm{~ms}$ TWT) is disrupted by several zones with transparent to highly discontinuous reflection patterns, which extend higher within the seismic volume under footwalls of major faults. It also contains chaotic parts. The data were analysed using Hampson Russell Software (HRS).

The methodology employed include rock physics cross-plots analysis and attribute generation from seismic data using simultaneous inversion. The rock physics cross-plots are useful in determining the rock properties/attributes that better discriminate fluids in the reservoir $[20,21]$. To investigate the lateral variations of reservoir properties away from the well bore, integration of reservoir properties derived from $\log$ data with seismic attributes was done. Lambda-rho $(\lambda \rho)$ and Mu-rho ( $\mu \rho)$ attributes, as proposed by Goodway et. al. [22], were extracted from the inverted seismic volumes. These attributes offer information about the rock's compressibility and rigidity which, also, rest upon pore fluid type and matrix properties of rocks. Other attributes considered in this work include acoustic impedance, Shear impedance and (Velocity ratio) $\mathrm{Vp} / \mathrm{Vs}$. These attributes are computed from both $\log$ and seismic. In the end, the results from the steps are scrutinized in other to understand the field, identify and evaluate the prospective zone with minimal uncertainty.

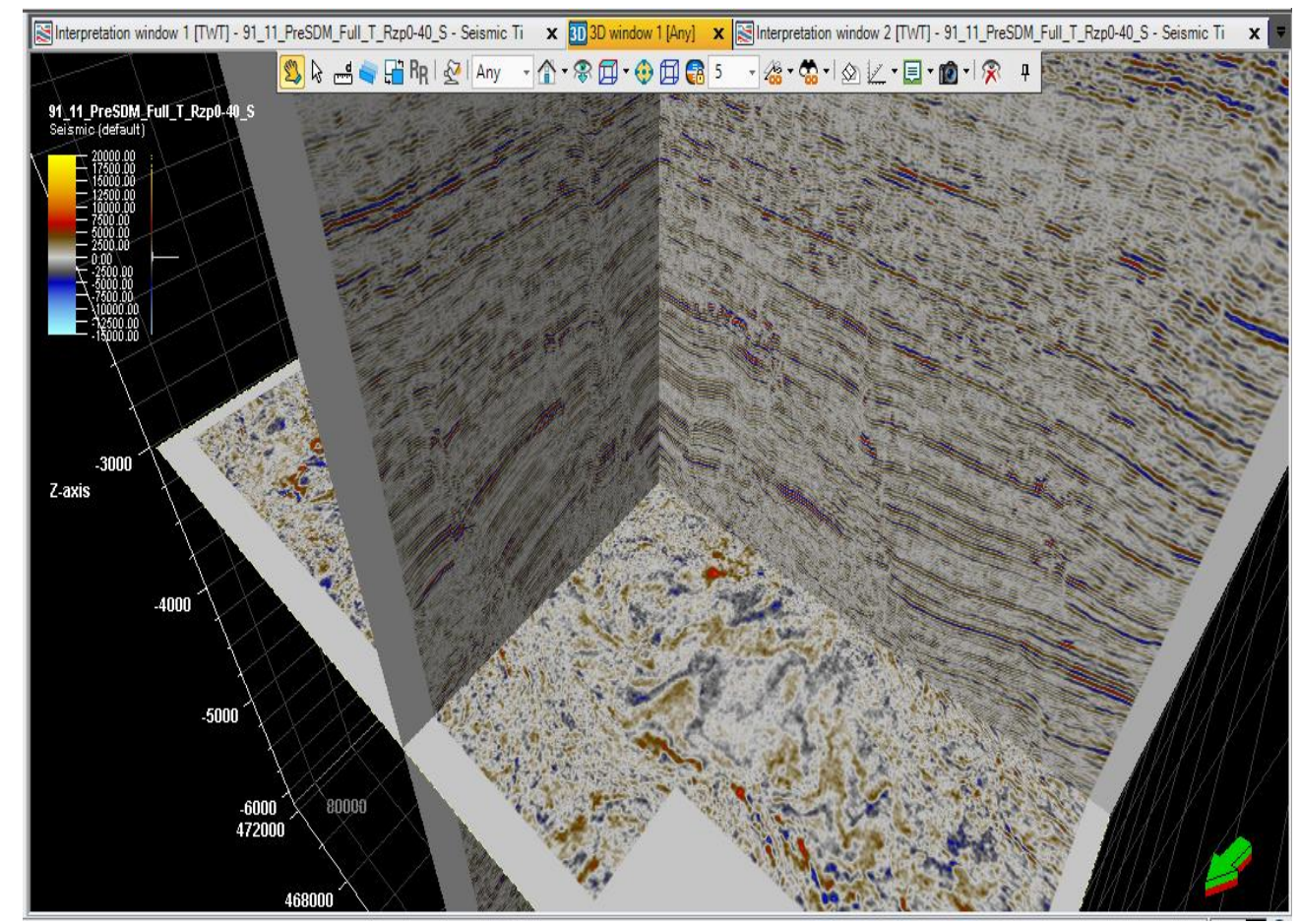

Fig. 2: Seismic data in 3-D view

Table 1: Well log inventory of available wells in Zeta field

\begin{tabular}{|c|c|c|c|c|c|c|c|c|}
\hline \multicolumn{2}{|c|}{ Well Information } & Well 1 & Well 2 & Well 3 & Well 4 & Well 5 & Well 6 & Well 7 \\
\hline \multicolumn{2}{|c|}{ Well Header } & Yes & Yes & Yes & Yes & Yes & Yes & Yes \\
\hline \multicolumn{2}{|c|}{ Well Reservoir Tops } & Yes & Yes & Yes & Yes & Yes & Yes & Yes \\
\hline \multicolumn{2}{|c|}{ Well Deviation Sets } & No & No & No & No & No & No & No \\
\hline \multicolumn{2}{|c|}{ Well Checkshot } & No & No & Yes & No & Yes & No & No \\
\hline \multirow{3}{*}{$\begin{array}{l}\exists \\
ت \\
3 \\
3\end{array}$} & GR & Yes & Yes & Yes & Yes & Yes & Yes & Yes \\
\hline & Sonic & Yes & Yes & Yes & No & Yes & Yes & No \\
\hline & Shear & Yes & No & No & No & Yes & No & No \\
\hline
\end{tabular}


International Advanced Research Journal in Science, Engineering and Technology

Impact Factor 7.105 $\div$ Vol. 9, Issue 1, January 2022

DOI: 10.17148/IARJSET.2022.9126

\begin{tabular}{|l|l|l|l|l|l|l|l|l|}
\hline & Restiv. & Yes & Yes & Yes & Yes & Yes & Yes & Yes \\
\cline { 2 - 8 } & Density & Yes & Yes & Yes & Yes & Yes & Yes & Yes \\
\hline & Calliper & Yes & Yes & Yes & Yes & Yes & Yes & Yes \\
\hline
\end{tabular}

\section{DATa SeTS AND Methodology}

\section{A. $\quad$ Crossplot of Mu-Rho $(\mu \rho)$ Versus Lambda-Rho $(\lambda \rho)$}

Cross-plot analysis helps to estimate and distinguish lithological and pore fluid units within the reservoir by using elastic constants and rock attributes, which have shown sensitivity to matrix and pore fluid. Compressional wave velocity to shear wave velocity is recognised to be a good attribute in discriminating fluid type [23]. Lambda-Rho ( $\lambda \rho)$ and Mu-Rho $(\mu \rho)$ have been shown by various researchers in hydrocarbon reservoirs to be robust discriminators of lithology and pore fluid [20, 24, 25]

Crossplots of Mu-rho $(\mu \rho)$ against Lambda-rho $(\lambda \rho)$ colour coded with volume of shale (Vshale) as the third dimension (Fig. 3 \& 4), show data clusters separated into four distinct zones inferred to be probable gas zone (purple), oil zone (blue), and brine (black) and shale (red), validated by lowest Vshale values. Low values of Lambda-rho $(\lambda \rho)$ and high values of Mu-rho $(\mu \rho)$ are associated with gas and oil saturations, while higher values of lambda-rho and low values of $\mathrm{Mu}$-rho correspond to brine saturation and shale. The plots indicate that lambda-rho is more robust than Mu-rho in the discrimination of fluids in this field, and that lambda-rho values are relatively low for the reservoir sand. Therefore, lambda-rho is expected to differentiate fluid better after the seismic data is inverted. Also, in the inverted section, differentiation into four zones as seen in the cross plots is expected. The cross plots actually aid in the interpretation of the inverted sections.
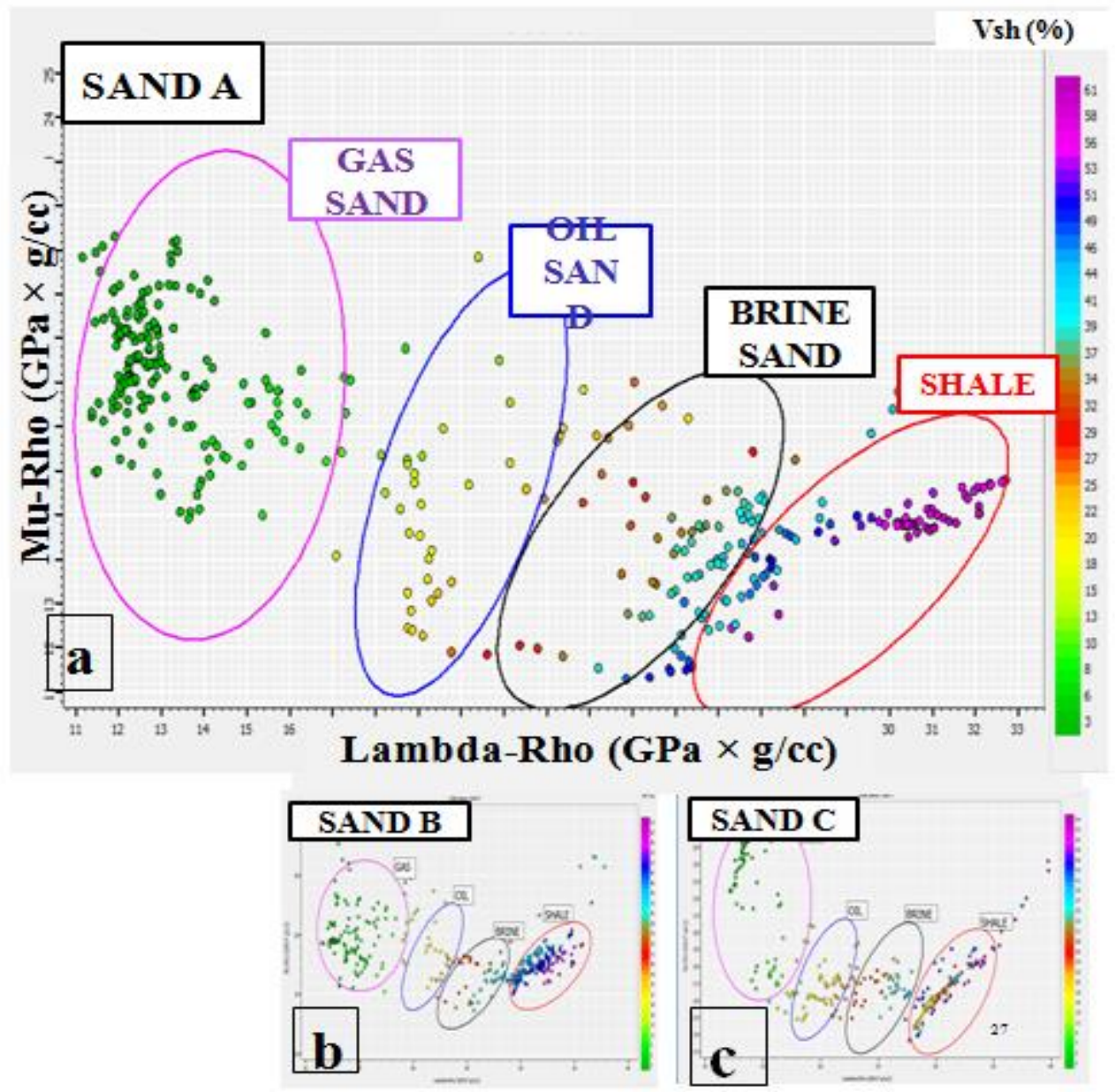

Fig. 3: Crossplot of Mu-rho versus Lambda-rho for Well 3 (a) Sand A (b) Sand B and (c) Sand C 

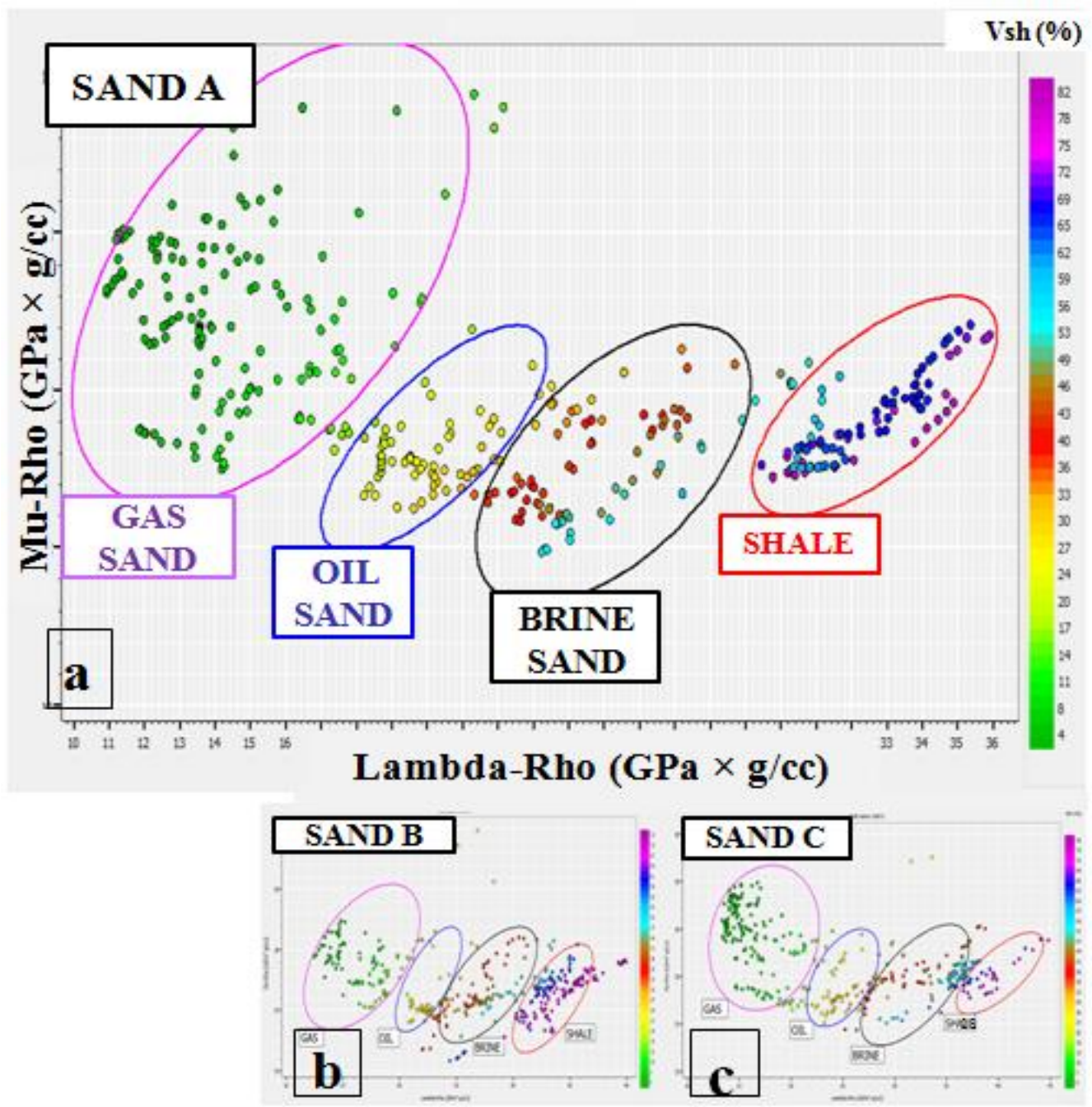

Fig. 4: Crossplot of Mu-rho versus Lambda-rho for Well 5 (a) Sand A (b) Sand B and (c) Sand C.

\section{B. Lambda-Rho $(\lambda \rho)$ Attribute Cross-section/Horizon Slice}

The lambda-rho attribute explains the incompressible nature of the lithology. Fig. 5 and 6 show inverted lambda-rho $(\lambda \rho)$ cross-section and horizon slices respectively for the field of study. The lithologies show sand and shale region and intercalation of sand shale typical of the Niger Delta. Low incompressibility values are well defined within the hydrocarbon charged zones. The embedding shale have higher values (29.7-35.0 Gpa*g/cc, Purple and Blue) of incompressibility. Lambda-Rho zone ranging from low to very low $(14.5-19.3 \mathrm{Gpa} * \mathrm{~g} / \mathrm{cc}$, Green and light yellow), which is consistent with the availability of hydrocarbon. Lambda-rho is low for oil sand and very low for gas sand. The reddish coloration $(21.1-26.3 \mathrm{Gpa}$ g/cc) observed corresponds to the effect of brine on Lambda Rho value. These observations agree with the behaviour of Lambda-Rho in the presence of hydrocarbon bearing sand and brine sand, as is seen in the generated cross plots involving Lambda-rho as one of the cross plotted properties. The slices in fig. $6 \mathrm{a}, 6 \mathrm{~b}$ and $6 \mathrm{c}$ show $\lambda \rho$ slices at Sand A, B and C respectively. Lambda-rho $(\lambda \rho)$ values ranges from low $11.4\left(\mathrm{Gpa}^{*} \mathrm{~g} / \mathrm{cc}\right)$ to as high as 35.4 $\mathrm{Gpa}^{*} \mathrm{~g} / \mathrm{cc}$. It has good discriminative capacity for reservoir fluids. Low values are indicative of hydrocarbon-charged sands, while higher values indicate brine sands. Hydrocarbon-charged sands have the lowest values of $\lambda \rho$. The well locations exhibit relatively low $\lambda \rho$ values, especially at Wells $3,4 \& 5$ locations at the SAND A, B and C Horizons 
International Advanced Research Journal in Science, Engineering and Technology

Impact Factor $7.105 \div$ Vol. 9, Issue 1, January 2022

DOI: $10.17148 /$ IARJSET.2022.9126

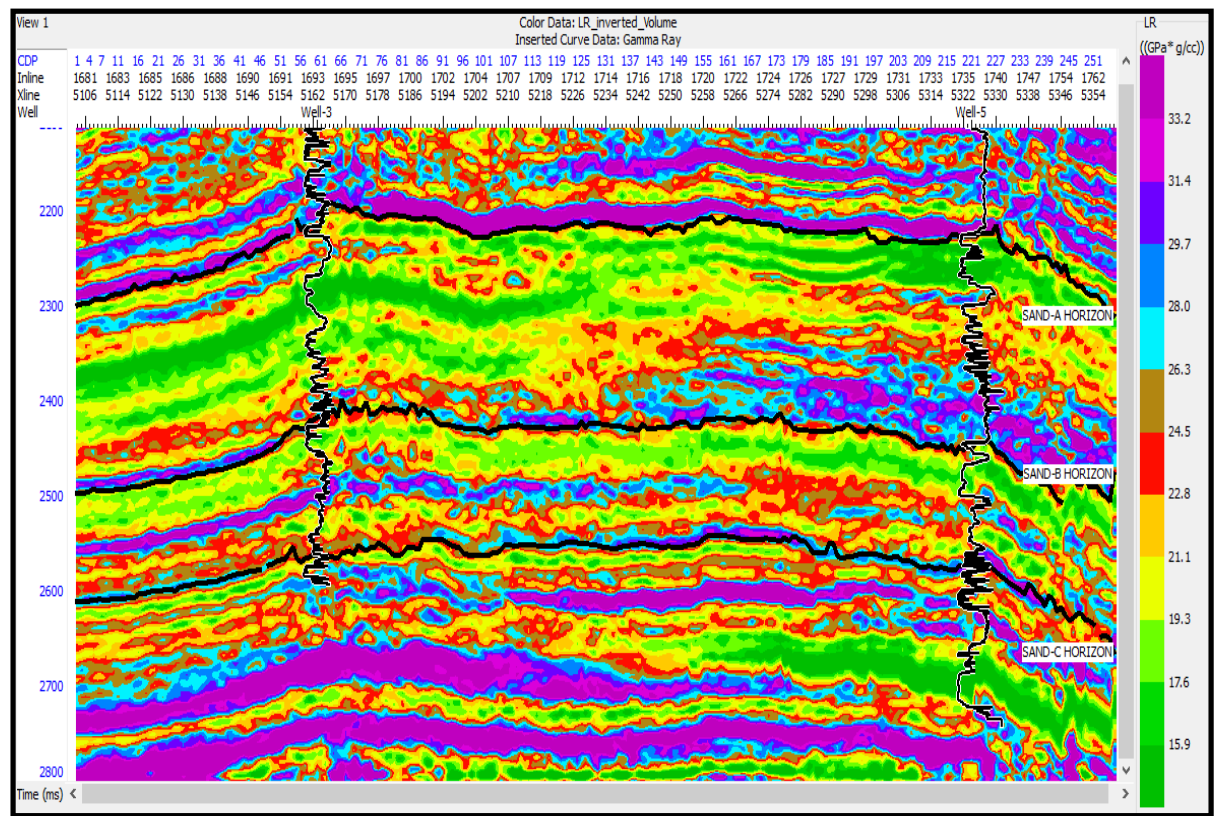

Fig. 5: Lambda-rho $(\lambda \rho)$ cross-section slice showing Well-03 \& Well-05. The gamma ray log characteristics have a good match to the inverted $\lambda \rho$. The Sand A, B \& C are bounded by low $\lambda \rho$

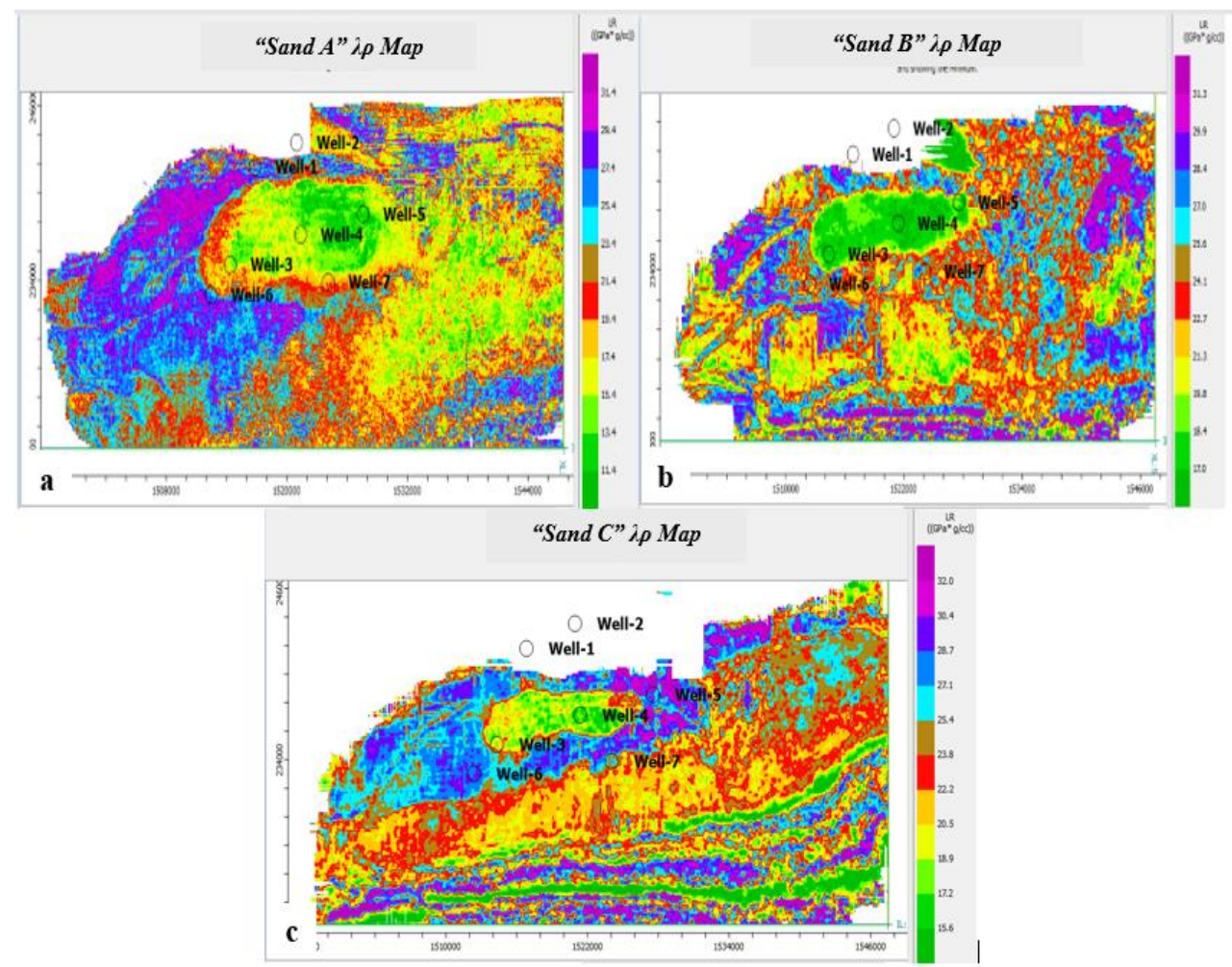

Fig. 6: The $\lambda \rho$ inverted horizon slices from the field showing the wells; (a) Sand A, (b) Sand B and (c) Sand C. Well 3 and Well 5 are bounded by low $\lambda \rho$ across SAND A, B, and C.

C. Mu-rho $(\mu \rho)$ Attribute Cross-Section/Horizon Slice

The Mu-rho attribute of Goodway et.al, gives quantitative measure of the variation in rigidity and hence, lithology. Fig. 7 and 8 show Mu-rho $(\mu \rho)$ attribute cross-section and horizon slices respectively. Mu-rho $(\mu \rho)$ values ranges from 2.1 $\mathrm{Gpa}^{*} \mathrm{~g} / \mathrm{cc}$ to as high as $28.6 \mathrm{Gpa} * \mathrm{~g} / \mathrm{cc}$. Depending on the sand quality, moderately compacted clean hydrocarbon filled reservoir sands exhibits relatively high values of mu-rho due to their high opposition to shearing, while unconsolidated clean hydrocarbon saturated reservoir formations exhibits low murho values. The north-eastern parts of the horizon slices (SAND A and SAND C) are in the region of relatively low mu-rho values, while western parts of the feild exhibit high 
International Advanced Research Journal in Science, Engineering and Technology

Impact Factor 7.105 Vol. 9, Issue 1, January 2022

DOI: 10.17148/IARJSET.2022.9126

mu-rho values (Fig. 8). Low and fairly high mu-rho values are probably due to to poor sand quality, suggestive of unconsolidated reservoir sands. The $\mu \rho$ attribute, however, is less discriminative of fluid when compared with the $\lambda \rho$ attribute.

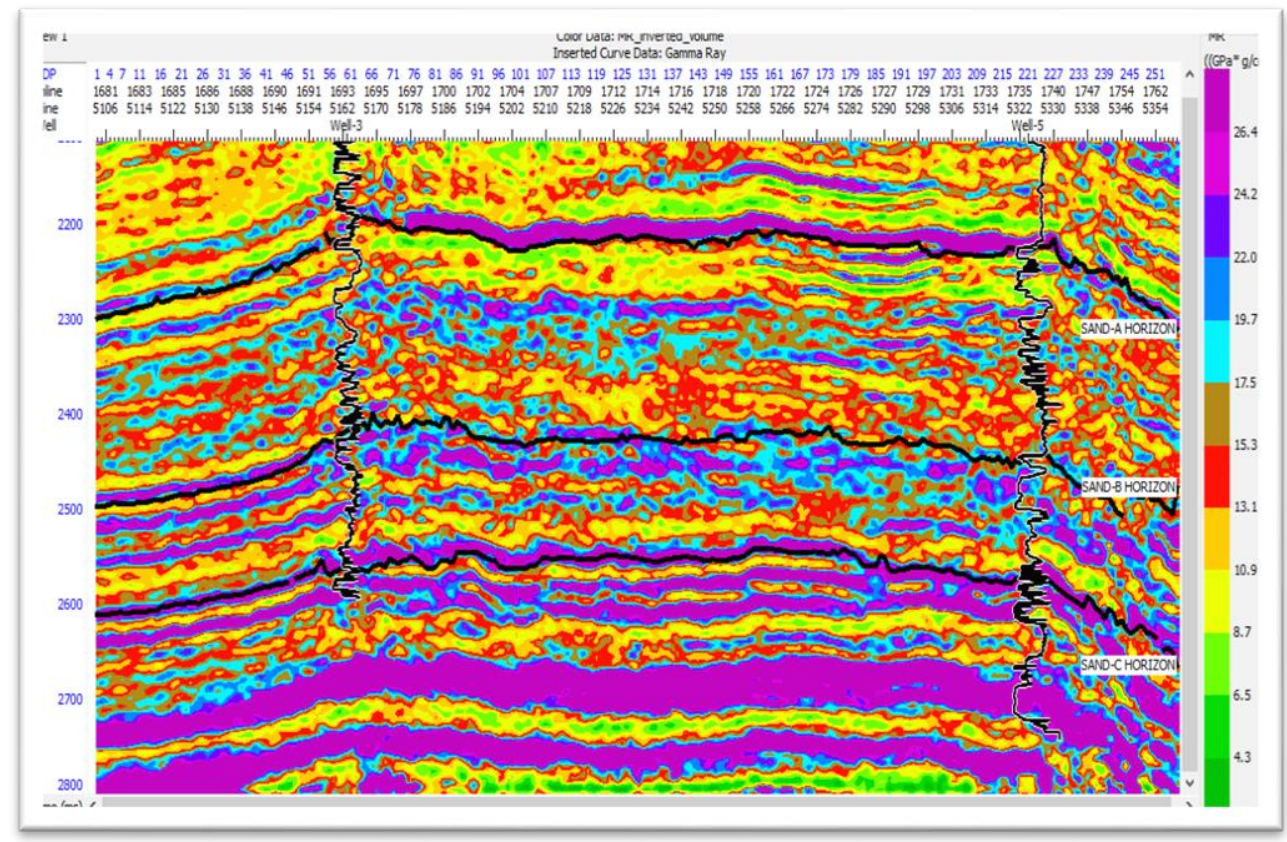

Fig. 7: Mu-rho $(\mu \rho)$ inverted cross-section slice showing Well-03 \& Well-05. The gamma ray log characteristics have a good match to the inverted $\lambda \rho$. The Sand A, B \& C are bounded by high $\mu \rho$

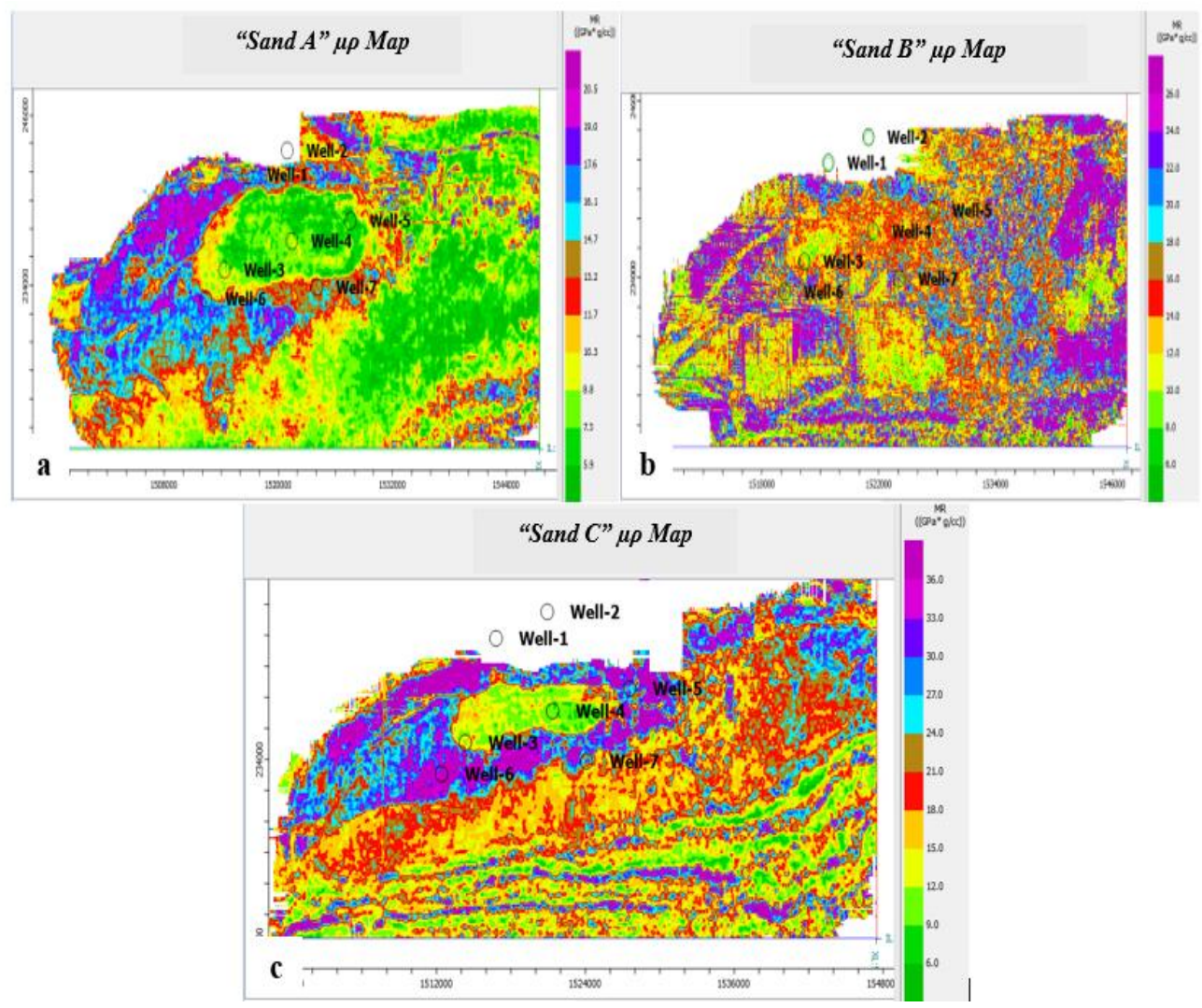

Fig. 8: Mu-rho $(\mu \rho)$ inverted horizon slices the field for (a) "Sand A" horizon, (b) "Sand B" horizon and (c) "Sand C" horizon 


\section{International Advanced Research Journal in Science, Engineering and Technology \\ Impact Factor $7.105 \div$ Vol. 9, Issue 1, January 2022 \\ DOI: 10.17148/IARJSET.2022.9126}

V. CONCLUSION

Simultaneous seismic inversion method was applied in this research to transform seismic reflections data into quantifiable rock properties. The steps in inverting the data included loading the data, seismic-to-well tie, wavelet extraction for the offset seismic volume, horizon interpretation, constructing well- and horizon-based low frequency Ip, Is, and density earth model, inversion parameter optimization, and quality check of the inversion outcomes. The inversion parameters were optimized to obtain the best possible Ip, Is, and density fit between the seismically derived values. Afterward, these parameters were used to obtain inverted sections for the entire seismic cube. Cross plots of Mu-Rho ( $\mu \rho)$ against LambdaRho $(\lambda \rho)$, revealed data clusters separated into four distinct zones inferred to be probable gas zone, oil zone, and brine and shale. Low lambda-rho values and high values of Mu-Rho rock attribute values are indicative of hydrocarbon saturated-sands. These values confirm the availability of oil and gas around Wells 3, 4 and 5 locations and to the Northwest of the horizon's slices. However, shale zones and brine are observed to the western part of the field and surrounding the hydrocarbon zones, indicating probable depleted zones and/or source rock. Results show that the lambda-rho attributes are relatively low around the well locations. These values confirm the availability of hydrocarbons around Wells $3,4 \&$ 5 location and to the North-west of the horizon's slices. Low lambda-rho values are indicative of hydrocarbon saturatedsands. However, shale zones and brine are observed to the western part of the field and surrounding the hydrocarbon zones, indicating probable depleted zones and/or source rock. The inversion indicates that lambda-Rho attribute is more diagnostic of fluid characterization. This study can be applied in the classification of rock properties; lithology and fluid characterization; avoidance of ambiguous amplitude interpretation that could lead to drilling dry wells; identification of new prospects as an effective economic and decision-making tool.

\section{ACKNOWLEDGMENT}

The authors are indebted to their colleagues in Department of Physics, Rivers State University for their contributions in the success of this work and editing of the manuscript. The authors acknowledge Shell, Port Harcourt, and Department of Petroleum Resources for release of the Data.

\section{REFERENCES}

[1] Amigun, J.O. and O.A. Odole, Petrophysical properties evaluation for reservoir characterisation of Seyi oil field (Niger-Delta). International Journal of Innovation and Applied Studies, 2013. 3(3): p. 756-773.

[2] Slatt, R.M., Stratigraphic reservoir characterization for petroleum geologists, geophysicists, and engineers. 2013: Newnes.

[3] Dewar, J. and S. Pickford, Rock Physics for the rest of us-An informal discussion. CSEG Recorder, 2001. 26(5): p. 42-49.

[4] Avseth, P., T. Mukerji, and G. Mavko, Quantitative seismic intrepretation. 2005, ISBN-10 0-521-81601-7, Cambridge University Press.

[5] Avseth, P., J. Dvorkin, G. Mavko, and J. Rykkje, Rock physics diagnostic of North Sea sands: Link between microstructure and seismic properties. Geophysical Research Letters, 2000. 27(17): p. 2761-2764.

[6] Burianyk, M. and S. Pickfort, Amplitude-vs-offset and seismic rock property analysis: A primer. CSEG Recorder, 2000. 25(9): p. 6-16.

[7] Mavko, G., T. Mukerji, and J. Dvorkin, The rock physics handbook: Tools for seismic analysis of porous media. 2009: Cambridge university press.

[8] Maurya, S., N. Singh, and K.H. Singh, Seismic Inversion Methods: A Practical Approach. 2020: Springer.

[9] Clochard, V., N. Delépine, K. Labat, and P. Ricarte, Post-stack versus pre-stack stratigraphic inversion for CO 2 monitoring purposes: a case study for the saline aquifer of the Sleipner field, in SEG Technical Program Expanded Abstracts 2009. 2009, Society of Exploration Geophysicists. p. 2417-2421.

[10] Bosch, M., T. Mukerji, and E.F. Gonzalez, Seismic inversion for reservoir properties combining statistical rock physics and geostatistics: A review. Geophysics, 2010. 75(5): p. 75A165-75A176.

[11] Klett, T., T. Ahlbrandt, J. Schmoker, and G. Dolton, Ranking of the world's oil and gas provinces by known petroleum volumes. 1997, US Dept. of the Interior, Geological Survey.

[12] Short, K. and A. Stauble, Outline of geology of Niger Delta. AAPG bulletin, 1967. 51(5): p. 761-779.

[13] Ekweozor, C. and E. Daukoru, Northern delta depobelt portion of the Akata-Agbada petroleum system. Niger Delta, Nigeria, in, Magoon, LB, Dow, WG eds., The Petroleum System--From Source to Trap, AAPG Memoir, 1994. 60: p. 599-614.

[14] Doust, H. and E. Omatsola, Niger delta. American Association of Petroleum Geologists Memoir, 1989. 48: p. 201-238. 


\section{International Advanced Research Journal in Science, Engineering and Technology \\ Impact Factor $7.105 \div$ Vol. 9, Issue 1, January 2022 \\ DOI: 10.17148/IARJSET.2022.9101}

[15] Ajakaiye, D.E. and A.W. Bally, Course manual and atlas of structural styles on reflection profiles from the Niger Delta. Vol. 41. 2002: American Association of Petroleum Geologists.

[16] Dim, C.I.P., K.M. Onuoha, C.G. Okeugo, and B.M. Ozumba, Petroleum system elements within the Late Cretaceous and Early Paleogene sediments of Nigeria's inland basins: An integrated sequence stratigraphic approach. Journal of African Earth Sciences, 2017. 130: p. 76-86.

[17] Olowoyo, K.O., Structural and Seismic Facies Interpretation of Fabi Field, Onshore Niger Delta, Nigeria. 2010: Universal-Publishers.

[18] Ekpo, B., N. Essien, P. Neji, and R. Etsenake, Geochemical fingerprinting of western offshore Niger Delta oils. Journal of Petroleum Science and Engineering, 2018. 160: p. 452-464.

[19] Doust, H., Petroleum geology of the Niger Delta. Geological Society, London, Special Publications, 1990. 50(1): p. $365-365$.

[20] Rasaq, B., C. Igwenagu, and Y. Onifade, Cross plotting of rock properties for fluid and lithology discrimination using well data in a Niger delta oil field. Journal of Applied Sciences and Environmental Management, 2015. 19(3): p. 539-546.

[21] Chioma, O., E. Uko, and I. Tamunobereton-ari, Determination of Lithology and Pore-Fluid of A Reservoir In Parts Of Niger Delta Using Well-Log Data. Journal of Applied Physics. 10(2): p. 71-82.

[22] Goodway, B., T. Chen, and J. Downton, Improved AVO fluid detection and lithology discrimination using Lamé petrophysical parameters;" $\lambda \rho "$, " $\mu \rho ", \&$ “ $\lambda / \mu$ fluid stack", from P and S inversions, in SEG technical program expanded abstracts 1997. 1997, Society of Exploration Geophysicists. p. 183-186.

[23] Hamada, G., Reservoir fluids identification using Vp/Vs ratio? Oil \& Gas Science and Technology, 2004. 59(6): p. 649-654.

[24] Dagogo, T., C.N. Ehirim, and J.O. Ebeniro, Enhanced prospect definition using well and 4d seismic data in a Niger Delta field. International Journal of Geosciences, 2016. 7(8): p. 977-990.

[25] Close, D., R. Taylor, and S. Nixon, A case study in quantitative interpretation ambiguity, lambda-mu-rho, and rock-physics modeling in the Otway Basin, Australia. The Leading Edge, 2016. 35(1): p. 43-50. 